\title{
SOCIAL WELFARE ORGANISATION IN POLAND
}

\author{
Radosław WOLNIAK \\ Politechnika Śląska, Wydział Organizacji i Zarządzania, Instytut Ekonomii i Informatyki; rwolniak@polsl.pl, \\ ORCID: 0000-0003-0317-9811
}

Purpose: The aim of the paper is to analyze social welfare system in Poland.

Design/methodology/approach: Critical literature analysis. Analysis of international literature from main databases and Polish literature and legal acts connecting with researched topic.

Findings: At the municipal level, the unit providing social assistance nearest to the citizen is the municipal or municipal social assistance centre. It is also the basic institution to which people in need come for help. Regional Social Policy Centres operate at the regional level, which are focused on creating social policy and promoting innovation in this area, as well as providing appropriate qualifications to social assistance staff. They are subject to Voivodship marshals. At the level of government administration, issues of social assistance belong to the Ministry of the Family, Labour and Social Policy. The scope of tasks of the Ministry of Family, Labour and Social Policy is extremely wide, therefore, some of the tasks in the field of social assistance have been delegated to local government units.

Originality/value: Detailed analysis of all subjects related to creating and managing social welfare policy in Poland.

Keywords: social welfares, social benefits, social economy, social responsibility, labour market.

Category of the paper: research paper.

\section{Introduction}

The beginnings of social assistance in Poland are connected with the activity of religious orders and various religious associations that carry out charity. There were also many foundations. Hospitals were established mainly by the Brothers of St. John, who also ran clinics at the monasteries. The first legal conditionality of social assistance was established in $1496-$ the management of the care of the mentally ill. This entity ran the records of beggars and issued certificates allowing them to beg. The first forms of governmental/municipal assistance date back to the beginning of the 12th century, and by the 17th century, assistance was well organized. An example can be the Olkusz miners' contribution to rescue and self-support 
themselves in case of accident. In the 17th century, the first orphanages and houses of improvement (so-called cucht hausy) were also established (Bochenek, 2018; Machelski, 2017; Maciejko, 2015).

In Poland, a characteristic feature of the development of social assistance was a gradual increase in the role of the state. Initially, this system was supported by numerous social organizations, because in the face of huge economic backwardness, the state's actions were not sufficient (Czajka, 2019).

An intentional activity of the state, social policy is aimed at improving working and living conditions of the population, as well as socio-cultural relations (Bragiel, and Badora, 2008; Broda-Wysocki, 2016; Pląsek, 2016; Haładus, 2019). The objective of social policy is social progress in the broadest sense, and therefore its activities relate to work, living conditions, culture and social order. Social policy activities are, therefore, extremely diverse. They cover the labour market, family assistance, health care, education, housing and many other areas. It is conducted both by central authorities, i.e. the government, as well as local governments or non-governmental organisations (associations, foundations, etc.). Social policy nowadays is also connected with social responsibility (Wolniak, 2013, 2016, 2017, 2018; Wolniak, and Hąbek, 2016; Hąbek, and Wolniak, 2013, 2016; Hys and Wolniak, 2016; Ponomarenko et al., 2016).

Social policy is understood at the same time as a practical activity (undertaken by various types of entities), as well as an interdisciplinary science that poses questions about the way of bettering living conditions and meeting people's needs. In terms of the demographic situation, significant factors for social policy are: the structure of the population, including the number of elderly people, the state of health of the population and the retirement age (Szarfenberg, 2016; Kamiński, 2015; Olkiewicz et al., 2019). Social economic policy is primarily the intent to counter unemployment and poverty, improve the skills and knowledge of citizens as well as the management of expenditure or sources of financing. In turn, the social situation is, e.g. the scale of addictions, pathologies in a given society, the amount of income and its diversification, the issue of social exclusion, etc. (Flaszyńska, 2018; Muszalski, 2015; Walc, and Szluz, 2008; Grebski, et al., 2019; Wolniak, et al., 2019; Wolniak, and Grebski, 2018; Wolniak, and Skotnicka-Zasadzień, 2018).

Social assistance means helping individuals, as well as whole families caught by difficult life situations. It is also about remediation of a situation in which these people are not be able to cope on their own even with their own powers, resources or abilities (Lewandowska, 2018; Łojko, 2015, 2017). Social assistance is an institution of social policy enacted by the state authorities. The state creates appropriate persons and organisations for the implementation of social assistance, task of which is to support citizens in meeting their essential needs, as well as to provide them with decent living conditions (Firlit-Fesnak, and Szylk-Skoczny, 2017; Szyszka, 2014). 
Social assistance can be given over both in cash and in and in nature through various types of support, advice or guidance (Rajski, 2016; Staręga-Piasek, 2016). The classification of social assistance can be made taking into account the dimension of this assistance. The beneficiaries may be granted periodic assistance until they become independent or, if this is impossible, permanent assistance. Social assistance can be ad hoc as well - i.e. of a mainly discretionary nature that is mainly influenced by the organizers' ability. Such help includes e.g. accommodation, provision of clothes or the serving of hot meals during the winter season (Auleytner, 2004; Kokoszkiewicz, 2015; Koąłczkowski, and Ratajczak, 2014; Łojko, 2015, 2017).

The aim of the paper is to analyse the current social welfare system in Poland.

\section{Legal conditions}

The social welfare system in Poland is regulated by several legal acts. These are, among others (Nitecki, 2017):

- The Act on Social Welfare of 12 March 2004.

- Family Benefits Act of 28 November 2003.

- Social Employment Act of 13 June 2003.

- Act on employment promotion and labour market institutions of 20 April 2004,

- Act on Social and Vocational Rehabilitation of the Disabled of 27 August 1997.

The first of these legal acts is the main and most important document regulating the shape of the social assistance system in Poland. It sets out, among other issues: tasks to be taken in the field of social assistance, types of benefits, organisation of social assistance, as well as rules and procedures of social assistance control. The Act also provides a definition of social assistance - that it is an institution of state social policy. Furthermore, it expressly states that social assistance is the responsibility of both governmental and local government administration bodies, and that these should cooperate with each other and with other social and nongovernmental organisations (Maciejko, and Zabomiak, 2013).

The Act on Social Welfare sees the mitigation of difficult life situations as being a social welfare task. Hence, social assistance is aimed at undertaking activities that satisfy the necessary needs of individuals and families so as to enable them to live in dignified conditions, to return to being independent and to reintegrate with their environment. For this reason, the Act introduces the principle that the type, form and amount of benefits should be adequate to a given situation. Persons in need, on the other hand, are obliged in this legal act to cooperate with responsible entities in solving their difficult life situation (Sierpowska, 2010). 
The Act on Social Assistance also states the limit to social assistance entitlement. Those who accept this must be persons of Polish citizenship (residing and staying in Poland) or foreigners who live and stay in Poland on the basis of a permit, refugee status, subsidiary protection, or in connection with a stay for humanitarian reasons (Bochenek, 2018).

Other beneficiaries of social assistance include (Rajski, 2016):

- citizens of European Union member states,

- citizens of Member States of the European Free Trade Agreement,

- nationals of the Agreement on the European Economic Area,

- citizens of the Swiss Confederation.

The condition for obtaining help is having the right of residence or the right of permanent residence in Poland. Such assistance is also granted to members of their families.

\section{The role of Social Welfare Centres}

Municipal Social Welfare Centres are institutions established to carry out their own social welfare tasks. Municipalities are obliged to establish and maintain them, and as the municipal community is the local government unit closest to the citizens, municipal-run social welfare centres are the basic institution to which people in need apply for assistance.

It should be mentioned that the designation for social welfare centres is not homogeneous, but usually the moniker 'Miejski Ośrodek Pomocy Społecznej' [Municipal Social Welfare Centre] is used in urban municipalities or 'Wiejskie Centrum Pomocy Społecznej' [Rural Social Welfare Centre] in rural municipalities.

The establishment of these centres may be the result of municipal initiative, or at the request of the mayor or president. These centres perform tasks resulting from the Social Welfare Act or other social welfare acts and regulations and local law passed by the municipal or town council. At the same time, the municipality are allowed to be independent in following terms of social welfare:

- principles of organization,

- management,

- functioning.

The social welfare centres operate on the basis of their statutes and regulations. The organizational structure of the centres varies depending on the size of the municipality and the scale of problems. For this reason, the most extensive structure is located within large cities. However, such a centre is always headed by a director, who is supervised by a mayor or president. At the same time, it is his duty to present an annual report on the activities of the social welfare centre to the commune or town council. He is also an employer for the centre's employees. 
The organisational structure of such a centre may consist of departments, sections or teams which directly perform the commune's social welfare tasks. Most often, there is a division of the centres into departments which carry out:

- environmental aid,

- benefits,

- care services,

- administration of the centre.

The tasks of individual departments are presented in Table 1.

Table 1.

The role of individual departments of the Social Assistance Centre

\begin{tabular}{|c|l|}
\hline Section & \multicolumn{1}{|c|}{ Activities } \\
\hline social welfare & - diagnosis of needs, \\
department & - support individuals and families in overcoming life's problems, \\
& - conducting environmental interviews, \\
& - doing social work, \\
& - providing assistance in the form of cash benefits, \\
\hline benefits department & - determining the right to benefits, \\
& - payment of benefits, \\
\hline caring department & $-\quad$ services for people with problems resulting from old age, illness, disability, lack of \\
& $-\begin{array}{l}\text { family and care, } \\
\text { matters (partially paid services). }\end{array}$ \\
\end{tabular}

Source: (Haładus, 2019).

The municipality may create other institutions that will perform social welfare-related tasks. Such institutions may be:

- welfare centres,

- occupational therapy workshops,

- community centres,

- homeless shelters,

- eating houses.

One of the tasks of social welfare centres is to cooperate with other institutions. Usually this cooperation is limited to entities operating in the same area of activity. The scale of this cooperation is different, as it depends on the possibilities and willingness to undertake joint initiatives. Cooperation with social organizations and nongovernmental organizations may have the following forms:

- providing information on social welfare activities to those concerned,

- assigning to entities certain tasks such as:

○ running day-care centres,

- running crisis intervention centres,

o organizing corrective gymnastics,

○ providing psychological counselling,

○ running support groups etc. 
In Poland, cooperation between the state and such non-governmental institutions as Caritas, the Polish Red Cross and the Children's Friends Society is the most extensive. Food aid is organized in cooperation with food banks, while cooperation with the Catholic Church takes the form of running canteens for the poor or organizing holidays for children and youth. The institution with which the social welfare centres establish close cooperation is the county labour office. This makes it possible to disseminate job offers, as well as information about training courses.

In terms of solving social problems resulting from social pathologies, social assistance centres undertake joint actions with the Police, Municipal Guard, local courts or school pedagogues.

On the basis of our analysis we can say that the social welfare centres are the institutions closest to the citizens and the basic institution to which they can go in case of failure to cope with difficult life situations. However, the work of these centres requires continuous cooperation with other entities within the social welfare system.

\section{Tasks of the Regional Social Policy Centres}

The Regional Social Policy Centres (ROPS) are an example of decentralised social policy. They are, in a way, the creators of this policy at regional level, while at the same time promoting innovation in this area. ROPS is an institution governed by the Voivodship marshal. Regional social assistance centres perform tasks in the field of social policy that are the responsibility of Voivodship self-government (Kołaczkowski, and Ratajczak, 2014).

These tasks arise from the Social Assistance Act and are relate to (Brenk, 2015):

- crafting and implementing the Voivodship strategy on social policy,

- running public social service schools,

- offering specialized training for social welfare personnel,

- creating regional social assistance programmes to support municipalities and districts,

- identifying the causes of poverty.

The obligatory task of the Voivodeship is to organise and run regional centres of social policy, as well as to provide funds for remuneration of its employees. In Poland, there are 11 Regional Social Policy Centres that have been separated from the Voivodship selfgovernment in organisational terms, and 5 centres located within the structure of the Marshal's

Office (Lubuskie, Pomorskie, Świętokrzyskie, Warmińsko-Mazurskie and Zachodniopomorskie Voivodeships). The largest centres employ over 50 people - these are the ROPS in: Katowice, Poznań, Toruń, Kraków and Łódź. Similarly to social welfare centres, ROPS have different organizational structures divided into teams, departments or independent positions. 
One of the most important tasks of the Regional Social Policy Centres is to carry out a social welfare needs assessment. In this case they are providing data necessary to secure an appropriate amount of funds for social welfare, as well as to identify the scale of social problems occurring in a given Voivodship. In relation to these problems and on the basis of these data, it is possible to update the social policy strategy and support solutions to these problems. The needs analysis made by ROPS include such categories of information as (Kowalska-Kantyka, and Kantyka, 2011; Baranowska, 2012):

- amount of security of funds for the implementation of benefits,

- running and maintaining social welfare units at local level,

- planned investments in social welfare institutions,

- needs relating to employment in social welfare institutions at municipal and county level,

- educational needs,

- scope of cooperation with NGOs, etc.

The role of the Regional Social Policy Centres is significant because they are providing appropriate qualifications to social assistance staff drawn from the whole region. At the same time, the centre performs most of the tasks assigned to the Voivodship self-government by the Act on Social Assistance (Szyszka, 2014; Szarfenberg, 2016; Staręga-Piasek, 2016; Kowalczyk, 2012).

\section{The Ministry of Family, Labour and Social Policy as coordinator of social policy}

In its current form, the Ministry of Family, Labour and Social Policy was established on 31 October 2005, and the name has been utilized since December 2015. This ministry deals with issues related to government administration matters concerning work, family and social security. There are three corresponding departments inside the organisational structure.

The main task of the Ministry of Family, Labour and Social Policy is to shape national social policy through (Borkowski et al., 2008):

- defining directions for action,

- preparing solutions,

- developing standards,

- monitoring the implemented solutions.

In addition, the Ministry is involved in the preparation of support programmes for persons and families who are at risk of social exclusion. Programmes of active forms of assistance are created for particular groups of people. The tasks of the ministry also include both creation and 
improvement of service standards in social assistance, social employment and environmental service units. Tasks concerning social assistance are performed by the minister in charge of social security.

The bodies directly subordinate to the Minister of Family, Labour and Social Policy are the Office for Veterans and Repressed Persons, Social Partnership Centre for Dialogue, and the Publishing and Printing Department of Ministry. The Minister of Family, Labour and Social Policy is also obliged to supervise the Central Institute for Labour Protection, Main Library of Labour and Social Security, Institute of Labour and Social Affairs, Voluntary Labour Corps, PFRON and the Social Insurance Institution.

The scope of tasks of the Ministry of Family, Labour and Social Policy is extremely wide, and the social welfare system itself in Poland can be regarded as extensive. For this reason, it was decided to entrust the tasks of government administration in the field of social welfare to local government units.

\section{Conclusion}

Currently, social welfare is an expression of the state's social policy, i.e. activities aimed at improving the living and working conditions of the population. This policy is influenced by demographic and economic factors, as well as the social situation of the state. Depending on the problems diagnosed, various forms and methods of social assistance are adopted. This assistance is offered only to those who are in a difficult life situation and would not be able to cope with their problems without the help of the state. The purpose of this assistance is to meet the living needs of citizens, as well as to support them in overcoming their difficulties and to return them to independence.

The Polish social assistance system provides for various forms of assistance of a monetary and non-monetary nature. The help provided must be adequate to the problems of the person or family and it can be ad hoc, periodic or permanent. Eligibility is ascertained by applying the income criterion and checking additional circumstances of the case.

The Polish social assistance system is quite developed and involves many institutions operating at various levels of government. It covers the cooperation of both local government units, social and non-governmental organizations. This system is regulated by laws, among which the most important is the Act on social assistance of March 12, 2004. Due to the wide range of issues to which social assistance relates, this system is governed by a greater number of laws and regulations.

At the municipal level, the unit providing social assistance nearest to the citizen is the municipal or municipal social assistance centre. It is also the basic institution to which people reach out to when in need for help. Regional Social Policy Centres operate at the regional level 
and are focused on creating social policy and promoting innovation in this area, as well as providing appropriate qualifications to social assistance staff. They are subject to Voivodship marshals. At the level of government administration, issues of social assistance belong to the Ministry of the Family, Labour and Social Policy. The scope of tasks of the Ministry of Family, Labour and Social Policy is extremely wide, therefore some of the tasks in the field of social assistance have been delegated to local government units.

\section{References}

1. Auleytner, J. (2004). Polska polityka społeczna. Warszawa: WSP.

2. Baranowska, M. (2012). Komentarz do ustawy o pomocy społecznej. Warszawa: Infor Ekspert.

3. Bochenek, M. (2018). Przyznawanie $i$ wypłacanie świadczeń rodzinnych. Warszawa: Wolters Kluwer.

4. Borkowski, Ł., Krajewski, R., Szymański, S. (2008). Komentarz do ustawy o pomocy spolecznej. Kutno: Wyd. Prawnicze Leges.

5. Bragiel, J., Badora, S. (2008). Formy opieki, wychowania $i$ wsparcia $w$ zreformowanym systemie pomocy społecznej. Opole: Uniwersytet Opolski.

6. Brenk, M. (2015). Ośrodki Pomocy Społecznej w systemie polityki społecznej państwa. Praca Socjalna, 5.

7. Broda-Wysocki, P. (2016). Pomoc spoteczna w Polsce - koncepcja i instrumenty. Warszawa: EAPN Polska.

8. Czajka, Z. (2019). Kompetencje pracowników pomocy społecznej w świetle świadczonych usług. Polityka Społeczna, 46, 18-24.

9. Firlit-Fesnak, G., Szylko-Skoczny, M. (2017). Polityka Społeczna. Warszawa: PWE.

10. Flaszyńska, E. (2018). Bezrobocie, bezrobotny, praca socjalna. Warszawa: Difin.

11. Grebski, M., Wolniak, R., Grebski, W. (2019). Nowa imigracja w północno-wschodniej części Pensylwanii Szanse i zagrożenia. Systemy Wspomagania w Inżynierii Produkcji, 1, 9-16.

12. Haładus, A. (2019). Systemy pomocy spolecznej w Polce. Praca magisterska napisana pod kierunkiem naukowym R. Wolniaka. Katowice.

13. Hąbek, P., Wolniak, R. (2013). Analysis of approaches to CSR reporting in selected European Union countries. International Journal of Economics and Research, 4(6), 79-95.

14. Hąbek, P., Wolniak, R. (2016a). Assessing the quality of corporate social responsibility reports: the case of reporting practices in selected European Union member states. Quality \& Quantity, 50(1), 339-420. 
15. Hąbek, P., Wolniak, R. (2016b). Factors influencing the development of CSR reporting practices: experts' versus preparers' points of view. Engineering Economy, 26(5), 560-570.

16. Hąbek, P., Wolniak, R. (2016c). Relationship between management practices and quality of CSR reports. Procedia - Social and Behavioral Sciences, 220, 115-123.

17. Hys, K., Wolniak, R. (2018). Praktyki przedsiębiorstw przemysłu chemicznego w Polsce w zakresie CSR. Przemyst Chemiczny, 9, 1000-1002.

18. Jachowicz, A. (2015). Funkcjonowanie pomocy społecznej. Dąbrowa Górnicza: WSB.

19. Kamiński, T. (2015). Gminna pomoc społeczna - ćwierć wieku transformacji. Przegląd Politologiczny, 4, 107-117.

20. Kokoszkiewicz, A. (2015). Opieka społeczna jako zadanie państwa. Lublin: Wydawnictwo Europejskiej Fundacji Przedsiębiorczości.

21. Kołaczkowski, B., Ratajczak, M. (2014). Pomoc społeczna. Wybrane instytucje pomocy rodzinie i dziecku. Warszawa: Wolters Kluwer.

22. Kowalczyk, B. (2012). Pomoc społeczna jako instytucja. Problemy Polityki Społecznej, 19.

23. Kowalska-Kantyka, M., Kantyka, S. (2011). Możliwości wsparcia rodzin $i$ osób dysfunkcyjnych przez ośrodki pomocy społecznej. Warszawa: WSP TWP.

24. Lewandowska, A. (2018). Ekonomia społeczna jako skuteczny instrument reintegracji społeczno-zawodowej. Europa Regionum, 36, 37-55.

25. Łojko, M. (2015). Pomoc społeczna wczoraj i dziś. Nowe wyzwania - stare problemy. Pomoc Społeczna Wczoraj i Dziś, 11.

26. Łojko, M. (2017). Pomoc społeczna jako instytucja publiczna w obszarze bezrobocia. Polityka Społeczna, 2, 19-24.

27. Machelski, T. (2017). Bezwarunkowy dochód podstawowy - refleksja prakseologiczna. Studia BAS, 2, 93-106.

28. Maciejko, W. (2015). Świadczenia rodzinne. Warszawa: C.H. Beck.

29. Maciejko, W., Zaborniak, P. (2013). Ustawa o pomocy społecznej. Komentarz. Warszawa: Lexis Nexis.

30. Muszalski, W. (2015). Prawo socjalne. Warszawa: PWN.

31. Nitecki, S. (2017). Prawo do pomocy społecznej w polskim systemie prawnym. Warszawa: Wolters Kluwer.

32. Olkiewicz, M., Wolniak, R., Grebski, E.M., Olkiewicz, A. (2019). Comparative analysis of the impact of the business incubator center on the economic sustainable development of regions in USA and Poland. Sustainability, 1(173), 1-22.

33. Pląsek, R. (2016). Pomoc społeczna i świadczenia rodzinne w Polsce - narzędzia włączającej zmiany czy utrwalania nierówności społecznych? Uniwersyteckie Czasopismo Socjologiczne, 14, 58-64.

34. Ponomarenko, T.V., Wolniak, R., Marinina, O.A. (2016). Corporate Social responsibility in coal industry (Practices of russian and european companies). Journal of Mining Institute, 222, 882-891. 
35. Rajski, G. (2016). Pomoc społeczna w praktyce. Gdańsk: ODDK.

36. Raport Poziom i struktura minimum socjalnego we wrześniu 2018 r. (2018). Warszawa: Instytut Pracy i Spraw Socjalnych.

37. Raport Wartość i struktura Wsparcia Dochodowego Rodzin (2018). Warszawa: Instytut Pracy i Spraw Socjalnych.

38. Sierpowska, I. (2010). Ustawa o pomocy społecznej. Komentarz. Warszawa: Wolters Kluwer.

39. Staręga-Piasek, J. (2016). Bilans potrzeb pomocy społecznej. Warszawa: IRSS.

40. Szarfenberg, R. (2016). Regionalne ośrodki polityki społecznej. Warszawa: Uniwersytet Warszawski.

41. Szyszka, M. (2014). Podręcznik wdrażania modelu wspólpracy instytucji z obszaru pomocy społecznej. Bielsko-Biała: Wyższa Szkoła Administracji.

42. Walc, W., Szluz, B. (2008). Opieka i pomoc społeczna wobec wyzwań wspótczesności. Rzeszów.

43. Wolniak R., Grebski M.E., Skotnicka-Zasadzień, B. (2019). Comparative analysis of the level of satisfaction with the services received at the business incubators (Hazleton, PA, USA and Gliwice, Poland). Sustainability, 10, 2889, 1-22.

44. Wolniak, R. (2013). The role of Grenelle II in Corporate Social Responsibility integrated reporting. Manager, 17(1), 7-21.

45. Wolniak, R. (2016a). Relations between corporate social responsibility reporting and the concept of greenwashing. Zeszyty Naukowe Politechniki Śląkiej. Seria Organizacji i Zarzadzanie, 87, 443-453.

46. Wolniak, R. (2016b). The relations between uncertainly avoidance and the concept of corporate social responsibility. Zeszyty Naukowe Politechniki Śląskiej. Seria Organizacji i Zarządzanie, 91, 291-307.

47. Wolniak, R. (2017a). Problematyka greenwashingu w aspekcie przemysłu 4.0. In: A. Kuzior (ed.), Rozważania różnorodne. Konferencja Rybnik. Zabrze: Śląskie Centrum Etyki Biznesu i Zrównoważonego Rozwoju, 83-93.

48. Wolniak, R. (2017b). Selected problems of professional career development of employees. Zeszyty Naukowe Wyższej Szkoty Humanitas, Zarzadzanie, 2, 9-20.

49. Wolniak, R. (2017c). The Corporate Social Responsibility practices in mining sector in Spain and in Poland - similarities and differences. Zeszyty Naukowe Politechniki Ślaskiej. Seria Organizacji i Zarzadzanie, 111, 111-120.

50. Wolniak, R. (2018a). Functioning of social welfare on the example of the city of Lazy. Zeszyty Naukowe Wyższej Szkoły, Humanitas. Zarzadzanie, 3, 159-176.

51. Wolniak, R. (2018b). Methods of recruitment and selection of employees on the example of the automotive industry. Zeszyty Naukowe Politechniki Ślaskiej. Seria Organizacja i Zarządzanie, 128, 475-483. 
52. Wolniak, R., Grebski, M.E. (2018a). Innovativeness and creativity as factors in workforce development - perspective of psychology, Zeszyty Naukowe Politechniki Ślaskiej. Seria Organizacja i Zarzadzanie, 116, 203-214.

53. Wolniak, R., Grebski, M.E. (2018b). Innovativeness and creativity as nature and nurture. Zeszyty Naukowe Politechniki Ślaskiej. Seria Organizacja i Zarządzanie, 116, 215-226.

54. Wolniak, R., Grebski, M.E. (2018c). Innovativeness and Creativity of the Workforce as Factors Stimulating Economic Growth in Modern Economies. Zeszyty Naukowe Politechniki Ślaskiej. Seria Organizacja i Zarządzanie, 116, 227-240.

55. Wolniak, R., Hąbek, P. (2016). Quality assessment of CSR reports - factor analysis. Procedia - Social and Behavioral Sciences, 220, 541-547.

56. Wolniak, R., Skotnicka-Zasadzień, B. (2018). Developing a model of factors influencing the quality of service for disabled customers in the condition s of sustainable development, illustrated by an example of the Silesian Voivodeship public administration. Sustainability, 7, 1-17.

57. www.ipiss.gov.pl, 14.01.2020. 